\title{
STUDI ANALISIS HUBUNGAN SELF-EFFICACY DENGAN HASIL BELAJAR
}

\author{
Nurul Hayati ${ }^{1 *}$, Muhammad Junus ${ }^{2}$, dan Riskan Qadar ${ }^{3}$ \\ $1^{*}, 2,3$ Program Studi Pendidikan Fisika, FKIP Universitas Mulawarman \\ JI. M. Yamin Samarinda, Kalimanan Timur, Indonesia \\ *E-mail Penulis Korespondensi: nurulhayati413@mail.com
}

\begin{abstract}
Abstrak
Penelitian ini bertujuan mengetahui seberapa besar hubungan self efficacy yang dimiliki siswa dan hasil belajarnya pada pembelajaran fisika sehingga mengacu kepercayaan diri yang dimiliki dan bisa menyelesaikan tugas yang diberikan disekolah dengan baik. Jenis penelitian ini dilakukan dengan metode penelitian Ex-Post Facto melihat adanya korelasi self efficaccy terhadap hasil belajar fisika dengan melewati tiga tahapan. Bentuk penelitian ini dipilih sebab menggunakan satu kelompok subjek populasi yang sekaligus menjadi sampel ini siswa kelas X SMK Negeri 6 Samarinda jurusan teknik pengelasan yang berjumlah sebanyak 34 siswa . pengumpulan data penelitian ini menggunakan tes berupa soal pilihan ganda sebanyak 20 butir dan angket sebanyak 20 pertanyaan untuk mendapatkan hasil hubungan antara self efficacy dengan hasil belajar fisika. Hasil penelitian menunjukkan pengaruh yang signifikan antara self efficacy siswa terhadap hasil belajarnya dengan melihat rentang nilai coefficcient bootstrap yang berada pada kutub yang sama yaitu nilai upper $-0,125$ dan lower $-0,848$ pada kutub negatif.
\end{abstract}

Kata kunci: Ex-Post Facto, self efficacy, hasil belajar fisika

\section{Abstract}

This study aims to determine how much the relationship between student self-efficacy and learning outcomes in learning physics so that it refers to the confidence they have and be able to complete the tasks given at school well. This type of research was conducted using the Ex-Post Facto research method, seeing a correlation between self-efficacy and learning outcomes of physics by passing through three stages. The form of this research was chosen because it used a group of population subjects who were at the same time a sample of grade $X$ students of SMK Negeri 6 Samarinda majoring in welding engineering, totaling 34 students. This research data collection using a test in the form of multiple choice questions as many as 20 items and a questionnaire of 20 questions to get the results of the relationship between self-efficacy and physics learning outcomes. The results showed a significant influence between student self-efficacy on learning outcomes by looking at the range of bootstrap coefficcient values that are at the same pole, namely the upper -0.125 and lower -0.848 values at the negative pole.

Keywords: Ex-Post Facto, self efficacy, physics learning outcomes.

Article History: Received: 12 Maret 2021

Accepted: 16 Maret 2021

Revised : 21 Maret 2021

Published: 30 April 2021

How to cite: Hayati, N., Yunus, M., \& Qadar, R. (2021). Studi Analisis Hubungan Self-Efficacy Dengan Hasil Belajar, Jurnal Literasi Pendidikan Fisika, 2 (1). pp. 83-91. Retrieved from http://jurnal.fkip.unmul.ac.id/index.php/JLPF

Copyright (C) April 2021, Jurnal Literasi Pendidikan Fisika 
Studi Analisis Hubungan..

\section{PENDAHULUAN}

Dalam hal mencapai pembelajaran yang terorganisasi dengan baik dapat kita lihat penerapan kurikulum 2013 sekarang ini mewajibkan sistem pembelajaran yang berbasis pendekatan saintifik dengan konsep dasar yang menginspirasi dan melatarbelakangi pembentukan metode mengajar dengan menerapkan karakteristik yang bersifat ilmiah untuk penyampaian pembelajarannya, dalam metode pendekatan saintifik ini menunutut siswa untuk dapat mengamati, menanya, mencoba atau mengumpulkan data, mengasosiasi atau menalar dan mengkomunikasikan. Pembelajaran jenis ini beroerientasi pada tingkat keaktifan siswa dalam melakasanakannya sedangkan guru hanya sebagai fasilitator maupun pengarah didalam proses belajar dan mengajar.

Kurikulum 2013 sangat menginginkan student centered dalam proses pembelajarannya dimana pada hal ini guru diwajibkan untuk sangat memperhatikan perbedaan individu pada setiap siswa karena setiap dari siswa memiliki karakteristik dan perbedaan masing-masing dalam hal menyerap hasil dari kegiatan pembelajaran yang diajarkan oleh seorang guru. Dalam hal perbedaan setiap individu dari siswa ditinjau dari perbedan dari kognitif, afektif, psikologis dan lainnya karena permasalahan yang muncul didalam diri siswa berhubungan dengan perilaku kognitifnya yaitu seperti terjadi ketidakselarasan antara keinginan dan minat pada individu dengan bakat khususnya, dan sebagai seorang guru harusnya mempertimbangkan pengaruh dari sikap dan nilai karakteristik kepribadian dengan prestasi dan partisipasi dalam kegiatan pembelajaran, guru perlu mengenali perbedaan dari setiap individu dan memperhatikan faktor-faktor yang berhubungan dengan faktor psikologis dalam diri siswa yaitu self efficacy, motivasi dan faktor lainnya.

Siswa sangat sering tidak bisa menujukkan prestasi akademiknya secara optimal sesuai pada kemampuan yang mereka punya. Salah satunya yaitu merasa tidak percaya diri dan tidak yakin akan dirinya sendiri mampu menyelesaikan tugas yang diberikan, padahal keyakinan sangat penting bagi siswa untuk memfokuskan diri dalam memilih tindakan, mengerahkan usaha, dan juga keuletan, dengan adanya keyakinan yang ada dalam diri siswa dan juga batas-batas kemampuan yang dirasakan akan menjadikan siswa merasa mantap dan efektif dalam menyelesaikan tugas, Spears dan Jordan (Pabiban, 2007) mempertegas bahwa siswa yang ada di sekolah dapat diantisipasi keberhasilan belajarnya jika siswa tersebut memiliki keyakinan yang besar bahwa iya bisa berhasil dan arti berhasil inilah yang sangat penting. Istilah keyakinan yang dimiliki siswa itulah yang disebut dengan self efficacy. Self efficacy juga merupakan suatu keyakinan dalam diri sebagai salah satu faktor personal yang merupakan perantara interaksi antara faktor perilaku dengan faktor lingkungan, dari besarnya keyakinan diri yang dipersepsikan maka akan memotivasi seseorang secara kognitif agar bertindak lebih terfokus, terutama jika tujuan yang ingin diraih adalah suatu tujuan yang sangat jelas (Ahriana, 2016).

Self efficacy dalam hal lain juga sering diartikan sebagai kemampuan yang dipersepsikan dan mengacu pada kepercayaan diri yang dimiliki oleh orang, yaitu kemampuan agar mampu menyelesaikan tugas yang diberikan dan jika mereka memiliki kemampuan untuk berhasil melakukannya maka biasanya mereka akan berusaha untuk mencobanya namun jika tugas itu dianggap terlalu sulit biasanya mereka akan berusaha untuk menghindarinya termasuk tugas yang menantang bahkan biasanya mereka akan menyerah ketika akan berusaha mencobanya dan hal ini biasanya terjadi pada orang yang memiliki efikasi diri yang rendah sehingga mereka seringkali menghubungkan hasil kegagalan mereka dengan kurangnya kemampuan yang dimiliki, dan ketika mereka berhasil biasanya mereka akan cenderung menghubungkan kesuksesan mereka dengan fakto-faktor eksternal, hingga pada akhirnya orang orang seperti ini akan cenderung kehilangan kepercayaan diri akan kemampuan yang mereka miliki ketika mereka mengalami kegagalan (Tenaw, 2013). Sehingga penelitian tentang efikasi diri dapat diakui sudah banyak diteliti baik diluar negeri maupun didalam negeri dengan variabel dan karakteristik subyek serta lokasi yang berbeda-beda. Yoannita (2016) membuat penelitian yang bermaksud agar bisa mengembangkan kemampuan 
Studi Analisis Hubungan..

pemecahan masalah dan self-efficacy matematis siswa di proses pembelajaran matematika bisa didapatkan hasil jika kemampuan dalam memecahkan masalah dan self efficacy siswa yang memiliki pendekatan dalam pengajaran Project Based Learning lebih bagus dibandingkan dengan kemampuan siswa yang mendapat pembelajaran konvensional, model pengajaran Project Based Learning didesign agar dimanfaatkan pada permasalahan komplek yang dibutuhkan siswa didalam melaksanakan investigasi dan memahaminya dalam proses pembelajaran berbasis proyek, siswa berhubungan dengan self efficacy yang tinggi untuk melakukan tugas proyek yang diberikan dengan sangat bertanggung jawab, tekun, ulet dan mengupayakan semua usaha serta kemampuannya agar bisa menyelesaikan tugas tersebut, dengan kalimat lainnya siswa yang mempunyai self efficacy yang rendah memungkinkan merasa tidak bisa dalam menuntaskan kerja proyek dan menjawab permasalahan yang diberikan.

Hal tersebut akan menghalangi jalannya dalam melaksanakan model pengajaran berbasis proyek dan berhubungan dengan rendahnya pada hasil belajar yang dimiliki siswa. Dan pada penelitian sebelumnya menerapkan model pengajaran inkuiri dalam meningkatkan self efficacy dan berfikir kritis siswa mengalami peningkatan secara kalsik serta penelitian yang dilakukan oleh para peneliti lainnya mereka berpendapat jika para pemikir kritis juga mempunyai kecakapan metakognisi berupa berpikir kecakapan metakognisi yaitu self efficacy yang butuh dikembangkan agar memunculkan kemampuan berpikir kritis.

Berdasarkan beberapa penelitian diatas yang sudah pernah dilakukan, ternyata self efficacy berperan sangat penting terhadap proses pembelajaran dalam meningkatkan hasil belajar. Maka dalam hal tersebut penelitian ini sangat penting untuk dilakukan agar kita mampu mengetahui dan membuktikan ada dan tidaknya hubungan antara self efficacy dan hasil belajar pada mata pelajaran fisika sehingga pada hal terkait permasalahan berupa model pembelajaran, pengembangan media pembelajaran, maupun pengembangan aplikasi untuk pembelajaran dalam meningkatkan hasil belajar siswa dapat diseusaikan setelah melihat hasil penelitian ini yang mengungkap serta membuktikan seberapa besar pengaruh yang terjadi pada self efficacy terhadap hasil belajar peserta didik (Zumro, 2018).

\section{METODE}

Penelitian yang dilakukan ini merupakan penelitian Ex-Post Facto untuk melihat adanya korelasi antara dua variabel yang akan diteliti dan didalam penelitian ini dilakukan melewati tiga tahapan yaitu, tahap untuk persiapan kemudian tahap pelaksanaan setelah itu tahap akhir seperti alur pada gambar

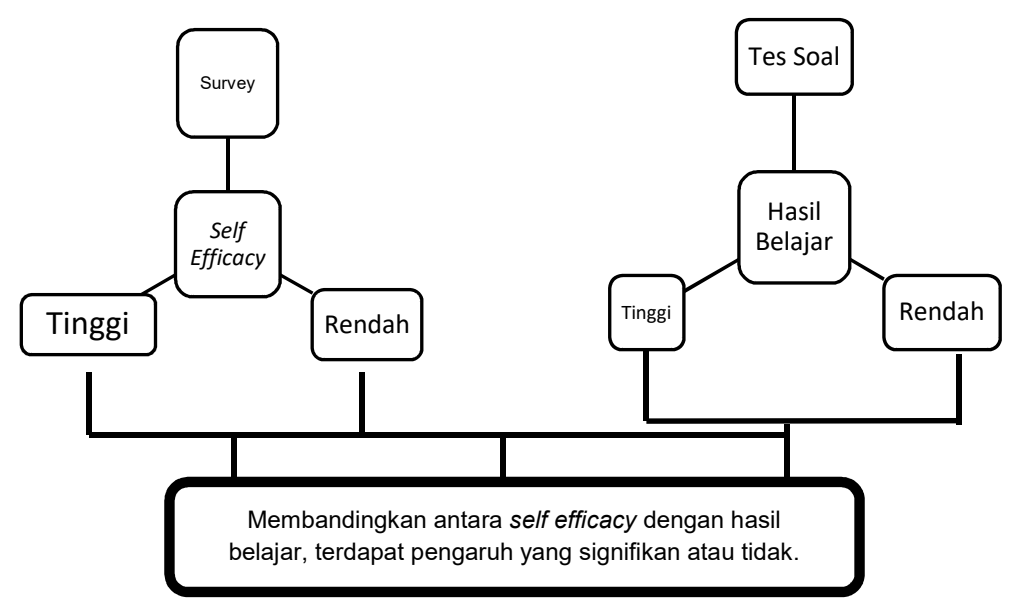

Gambar 1. Alur Penelitian 
Studi Analisis Hubungan..

Dari alur penelitian seperti gambar diatas maka tiga tahapan yang bisa dilakukan seperti berikut:

1. Tahap Persiapan

Aktivitas yang dikerjakan pada langkah ini yaitu :

a) Menghubungi pihak sekolah terutama kepala sekolah dan juga guru yang mengajar fisika dengan tujuan ingin meminta izin akan melakukan penelitian disekolah tersebut.

b) Menyusun pertanyaan sebagai isi dari angket self efficacy yang akan diteliti.

2. Tahap Pelaksanaan

Pada langkah ini merupakan bagian awal untuk peneliti mulai membagikan angket self efficacy yang sudah dibuat dan juga soal sebagai tes hasil belajar.

3. Tahap Akhir

Sesudah semua aktivitas dari segala langkah penelitian diatas telah dilaksanakan maka mulai dilakukan analisis dari data yang sudah didapat agar bisa mengetahui seberapa berhasil tujuan dari penelitian yang sudah terjawab.

Setelah selesai melakukan ketiga tahapan tersebut kita lanjutkan pada teknik pengumpulan data dan instrumen penelitian yang akan digunakan, yaitu pertama hasil belajar fisika yang didapat melewati tes beberapa soal untuk mengetahui hasil belajar fisika siswa pada materi impuls dan momentum (Ahriana, 2016: 233) dengan bentuk soal berupa pilihan ganda dan meliputi 5 pilihan untuk menjawab pertanyaan yaitu a,b,c, d, dan e dengan jumlah soal sebanyak 20 soal dan indikator soal sudah disesuaikan dengan taksonomi bloom yang meliputi ingatan, pemahaman, aplikasi, dan analisis dengan pembagian komposisi jumlah soal seperti pada Gambar 2.

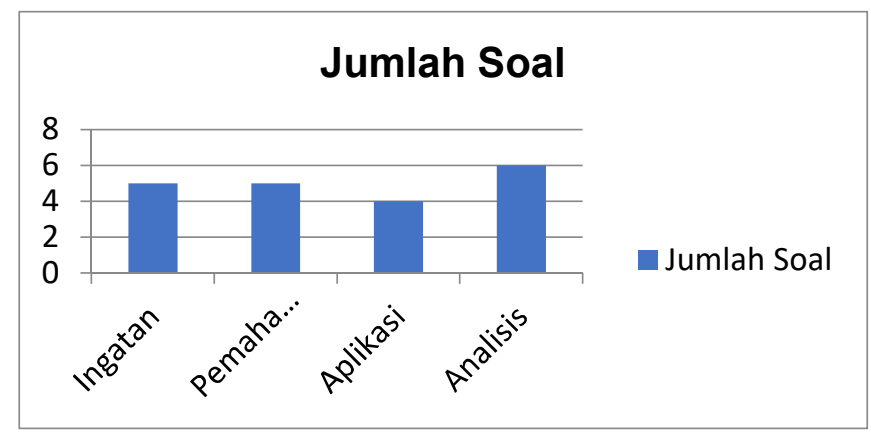

Gambar 2. Grafik Soal Pembelajaran Fisika

Kemudian instrumen angket self efficacy diatur didalam bentuk skala Likert dengan lima pilihan

jawaban yaitu sangat setuju (SS), setuju (S), ragu-ragu (RG), tidak setuju (TS) dan sangat tidak setuju (STS) dengan indikator dari komponen magnitude, generally dan strength, Instrumen ini terdiri atas 20 butir dan telah disusun berdasarkan tingkat dari keyakinan siswa.

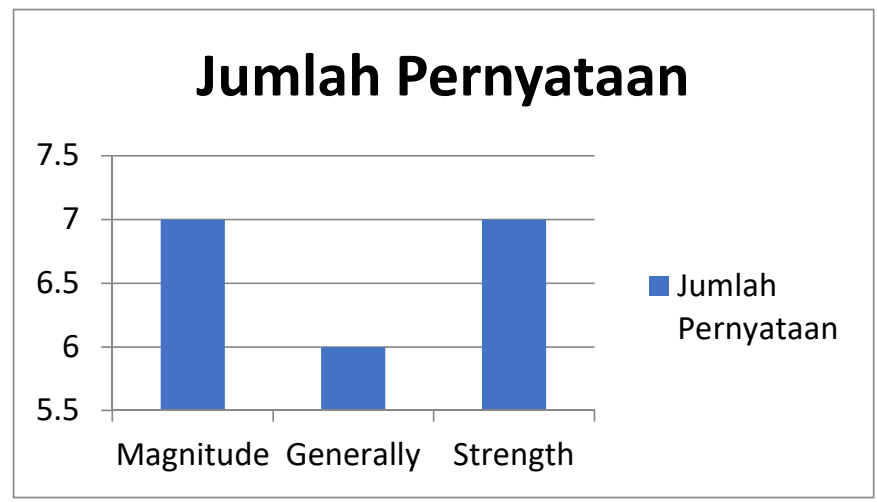

Gambar 3. Grafik Angket Pernyataan Self-Efficacy 
Studi Analisis Hubungan..

Pada teknik analisis data pertama yang dilakukan dengan analisis deskriptif yang mencakup ratarata, rentang, standar deviasi dan juga kategori. Kedua dengan anali sis statistik inferensial yaitu dilakukan dengan uji normalitas terlebih dahulu kemudian yang terakhir dilakukan uji hipotesis.

\section{HASIL DAN PEMBAHASAN}

\section{HASIL}

Pada hasil analisis deskriptif yang dilakukan dalam variabel self efficacy dan variabel hasil belajar maka rangkuman data statistik untuk mendapatkan keseluruhan nilai rata rata, standar deviasi maupun rentang nilai pada skor self efficacy dan juga hasil belajar para peserta didik dengan menggunakan SPSS tipe 23 melalui uji deskriptif untuk menguji data di kelas X SMK Negeri 6 Samarinda pada tahun ajaran 2019-2020 sehingga bisa dilihat pada Tabel 1 dan Table 2.

Tabel 1. Analisis Deskriptif Self Efficacy

\begin{tabular}{ccccc}
\hline Mean & $\begin{array}{c}\text { Standar } \\
\text { Deviasi }\end{array}$ & Maximum & Minimum & Range \\
\hline 61,65 & 7,286 & 79 & 50 & 29 \\
\hline
\end{tabular}

Tabel 2. Analisis Deskriptif Hasil Belajar

\begin{tabular}{ccccc}
\hline Mean & $\begin{array}{c}\text { Standar } \\
\text { Deviasi }\end{array}$ & Maximum & Minimum & Range \\
\hline 51,62 & 9,188 & 70 & 35 & 35 \\
\hline
\end{tabular}

Nilai rata rata pada variabel self efficacy sebesar 61,65 dengan standar deviasi 7,286 yang artinya data yang diperoleh akurat, kemudian skor maximum 79 dan skor minimum 50 dengan rentang skor 29 sedangkan pada variabel hasil belajar nilai 51,62 dengan stndar deviasi 9,188 yang berarati juga data pada variabel hasil ini juga akurat dengan skor maximum 70 dan skor minimum 35 yang berarti rentang skor 35. Kemudian untuk melihat hasil keseluruhan dari angket self efficacy dengan melihat 3 aspek yang sudah ada dalam angket tersebut maka kita bisa melihat pada Gambar 4.

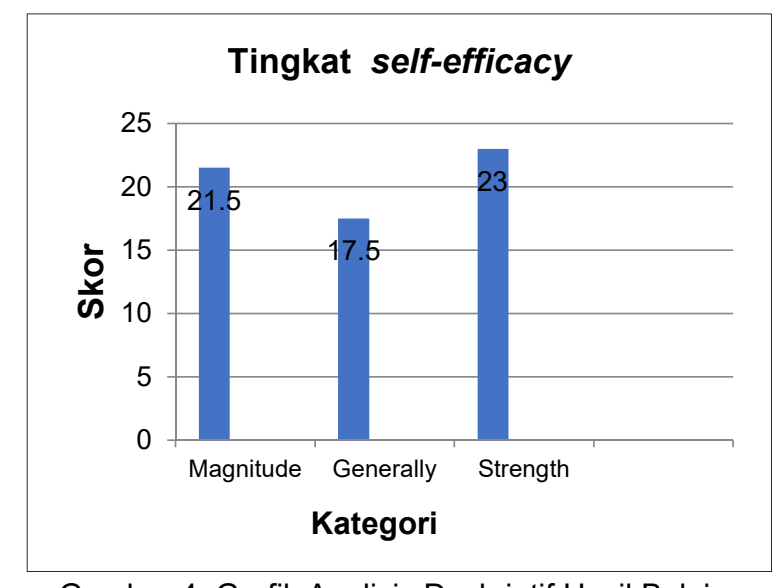

Gambar 4. Grafik Analisis Deskriptif Hasil Belajar

Dalam grafik ini terlihat bahwa tingkat self-efficacy siswa dalam aspek strength yaitu keyakinan akan kemampuan mencapai target meskipun ada banyak hambatan terilhat lebih tinggi dari aspek lainnya sedangkan aspek generally yaitu keyakinan akan berhasil pada tugas yang hanya mencakup satu bidang sampai pada yang mencakup lebih dari satu bidang ini berada pada tingkat yang lebih rendah dari aspek lainnya.

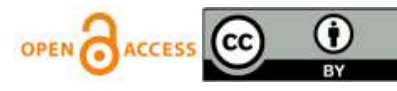


Studi Analisis Hubungan..

1. Uji Normalitas

Sebelum melakukan analisis statistik inferensial terlebih dahulu melakukan uji prasyarat analisis yaitu uji normalitas dimana disini uji normlitasnya dilakukan dengan cara bootstrapping sample untuk menormalkan data.

Tabel 3. Bootstrap Sample

\begin{tabular}{ll}
\hline Number of Samples & 2000 \\
\hline Confidence Interval Level & $95,0 \%$ \\
\hline
\end{tabular}

Pada tabel diatas dapat kita lihat bahwa data sampel asli dari hasil penelitian kita telah di resample hingga 2000 kali dengan tingkat kepercayaan sebesar $95 \%$ hingga tidak diperlukan asumsi normalitas lagi, Selain itu metode bootstrapping seperti ini juga digunakan untuk menyelesaikan model regresi linier, baik sederhana maupun berganda.

2. Uji Linearitas

Untuk menguji linearitas regresi pada data hasil belajar fisika atas angket self efficacy. (Safitri, 2015) Model regresi linear yang digunakan adalah bootstarpping multiple regression pada SPSS yaitu menguji regresi kelinearitasan data dengan bootstrap untuk melihat besarnya signifikansi pengaruh antara variabel self efficcacy terhadap variabel hasil belajar fisika peseta didik, maka data statistiknya dapat dilihat pada Tabel 4.

Tabel 4. Bootstrap Multiple Regression

\begin{tabular}{ll}
\hline Model & Sig. (2-tailed) \\
\hline Nilai angket &, 017 \\
\hline
\end{tabular}

Dari tabel diatas dapat dilihat dengan taraf kepercayan 95\% antara skor dari self effciacy dengan hasil belajar fisika linear karena taraf signifikannya lebih kecil dari 0,05 yaitu 0,17 yang berarti terjadi pada variabel self efficacy sangat signifikan pengaruhnya terhadap hasil belajar fisika siswa.

3. Uji Hipotesis

Uji hipotesis ini dilakukan agar kita dapat mengetahui bahwa ada dan tidaknya hubungan antara self efficacy terhadap hasil belajar fisika siswa seperti berikut.

Tabel 5. Confidence Interval Uji Hipotesis

\begin{tabular}{ccc}
\hline \multirow{2}{*}{ Model } & \multicolumn{2}{c}{ BCa 95\% Confidence Interval } \\
\cline { 2 - 3 } & Lower & Upper \\
\hline Nilai angket &,- 848 &,- 125 \\
\hline
\end{tabular}

Maka analisis data ini dikatakan signifikan jika batas atas dan batas bawah berada pada kutub yang sama dan hasil analisis data yang telah dilakukan menunjukkan nilai upper -0,125 dan lower $-0,848$ hal ini menunjukkan bahwa hipotesis $\mathrm{H} 0$ ditolak dan Ha diterima yang berbunyi bahwa self efficaccy siswa signifikan pengaruhnya terhadap hasil belajar fisika. Dapat juga dikatakan bahwa semakin tinggi self efficacy siswa maka semakin bagus atau semakin tinggi juga nilai hasil belajar siswa pada mata pelajaran fisika tersebut.

\section{PEMBAHASAN}

Hipotesis yang telah diajukan dalam penelitian tersebut diatas ternyata ada hubungan yang signifikan antara self efficacy terhadap hasil belajar fisika siswa. Dalam hal ini dapat kita lihat dari nilai 
Studi Analisis Hubungan..

hasil analisis uji bootstarpping multiple regression yang digunakan untuk melihat kelinearitasan data dan dalam menentukan keputusan hipotesis yang sudah dibuat.

Dengan diterimanya hipotesis alternatif dalam keputusan hasil analisis data yang telah digunakan dapat dilihat dari rentang nilai pada coefficient bootstrap batas nilai upper $-0,125$ dan lower $-0,848$ yang berada pada kutub yang sama yaitu negatif maka dalam hal ini bisa kita artikan bahwa semakin seorang siswa itu memiliki self efficacy yang tinggi maka semakin besar kemungkinan siswa itu akan mendapatkan nilai atau hasil belajar fisika yang tinggi juga.

Jika dikaitkan antara angket self efficacy dengan soal fisika yang dibuat maka pengetahuan siswa tentang seberapa dalam pemahaman materi yang ada dalam soal dapat diukur lewat angket karena pertanyaan pada angket semuanya menjurus kepada materi yang akan dipertanyakan dalam soal nantinya, pada pertanyaan angket self efficacy yang dibuat semua pertanyaan seakan akan siswa yang membaca sedang bertanya pada dirinya sendiri untuk mengetahui seberapa pahamnya iya tentang materi yang sudah diajarkan sebelumnya, dalam hal ini justru membantu siswa untuk mengenali bagaimana cara menemukan keyakinan akan kemampuan yang iya miliki dalam memahami suatu pembelajaran yang sudah dijelaskan dalam teori self efficacy bahwa self efficacy itu merupakan suatu kemampuan yang mampu mengacu pada kepercayaan diri yang dimiliki oleh orang tersebut. Maka dari itu ketika siswa sudah menjawab soal yang diberikan seharusnya siswa sudah mengetahui seberapa mampu menjawab pertanyaan dengan benar sesuai angket yang sudah diisi, namun beberapa faktor terkadang pada angket siswa menjawab ragu ragu namun pada soal mampu menjawab dengan benar pertanyaan yang ada karena siswa tersebut masih ragu dengan keyakinan ingatannya untuk memahami materi yang sudah diajarkan sedangkan ada juga yang sudah menjawab angket sangat setuju ataupun setuju namun pada soal menjawab masih salah dikarenakan ada beberapa soal yang mereka perkirakan hanya sekedar memasukkan pada rumus tanpa perlu dianalisis lebih dalam sehingga jawaban siswa beberapa ada yang salah dalam menjawab soal tersebut.

Dari hasil analisis data dalam penelitian yang sudah dilakukan diatas menunjukkan bahwa tingkat self efficacy siswa SMK Negeri 6 Samarinda cukup tinggi dalam menyesaikan soal soal pada mata pelajaran fisika, meskipun dalam beberapa soal yang diberikan siswa rata rata hanya mampu menyelesaikan soal dengan benar sebanyak 10 sampai 12 soal dari 20 soal yang diberikan, sebenarnya dalam hal ini disebabkan ada beberapa siswa yang masih ragu dengan kemampuannya dan juga ada sekitar 3 soal yang siswa banyak salah dalam menjawabnya. Jawaban yang salah dikarenakan siswa hanya mengetahui rumus umum dari impuls dan momentum tanpa mengetahui hubungan antara keduanya dan uraian dari rumus impuls maupun momentum. seperti impuls adalah gaya dikali selang waktu, sedangkan gaya jika diuraikan maka menjadi massa dikali percepatan, jika dihubungkan maka berkaitan dengan hukum 1 Newton dimana gaya pada impuls dipengaruhi massa dan kecepatan dari benda tersebut, selain pengaruh dari selang waktunya. Pada dasarnya siswa tidak memahami maksud dari soal terkait apa yang sebenarnya diminta untuk diperhitungkan, dan ada beberapa siswa yang masih belum mengerti bagaimana mengkonversi satuan, seperti dari satuan kilometer ke satuan meter sehingga hasil yang didapat berbeda dengan jawaban yang sebenarnya, dan siswa kebanyakan hanya langsung memasukkan angka kedalam rumus tanpa mengkonversi terlebih satuan yang ada dahulu, sehingga mendapatkan hasil yang salah meskipun dipilihan jawaban hasil yang mereka hitung juga ada sebagai jawaban, hal inilah yang membuat siswa merasa sudah benar dalam menjawab. Namun aspek lainnya juga yaitu terkendala waktu yang cukup singkat disekolah sehingga siswa tergesa gesa untuk segera menyelesaikan soal dan tidak terlalu memmahami secara mendalam pertanyaan yang ditanyakan. Namun ada juga permasalahan angket siswa yang terlalu tinggi dan terlalu rendah karena tidak memahami bahwa pada pertaanyaan angket tersebut memuat pertanyaan positif dan negatif, karena beberapa siswa tidak membaca dengan benar sehingga langsung mengissi setuju atau tidak setuju.

Pada pembahasan self efficacy ini para siswa juga mempunyai self efficacy yang tinggi berkaitan dengan tiga komponen self efficacy yaitu komponen magnitude dimana seorang siswa merasa yakin

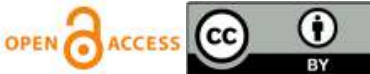


Studi Analisis Hubungan..

berhasil pada tugas yang butuh pemikiran sederhana sampai pada tugas yang butuh pemikiran sedang, kemudian pada komponen generally yaitu dimana seorang siswa merasa bahwa akan berhasil pada tugas-tugas yang mencakup satu bidang saja sampai yang mencakup lebih dari satu bidang, serta komponen strength yaitu seorang siswa tetap merasa yakin dan berusaha mencapai target meskipun banyak hambatan dan tekun dalam menyelesaikan tugas sekolah dengan baik.

Selain dari ketiga komponen diatas ada juga aspek lainnya seperti dukungan dari teman teman disekelilingnya yang memberikan respon positif pada saat dikelas untuk mendapatkan nilai yang bagus pada mata pelajaran fisika, karena kadang jika teman temannya disekeliling memberikan respon yang negatif itu akan sangat berpengaruh pada sel efficcacy seorang siswa itu sendiri, keyakinan seorang siswa akan sangat berkurang terhadap kemampuannya sendiri bahwa ia mampu menyelesaikan tugas yang diberikan terutama pada mata pelajaran fisika, dan hal inilah yang berakibat pada hasil belajar siswa yang menurun atau tidak bagus. Kemudian aspek lainnya yaitu juga pengaruh respon seorang guru terhadap siswanya sendiri selama pelajaran berlangsung, misalnya ketika seorang siswa bertanya usahakan untuk mengapresiasi tentang pertanyaan yang diberikannya dan memberikan kebebasan kepada siswa untuk berpendapat tanpa menyalahkannya karena hal ini sangat berpengaruh cukup besar juga terhadap self eficcacy siswa itu sendiri. Jika kita tidak mengapresiasinya dan menyalahkannya hal ini akan membuat rasa keingintahuannya untuk bertanya lagi tentang hal hal yang belum ia ketahui tidak akan ia sampaikan dan akan diurungkannya sehingga ia hanya memendam pertanyaan itu dalam fikirannya sendiri.

Dari banyak aspek yang telah kita bahas diatas, yang perlu kita ketahui bahwa setiap seorang siswa yang sedang menempuh pendidikan disekolah memang sangat diharapkan agar memiliki keyakinan atau kepercayaan diri yang bagus untuk memperhitungkan kemampuan dirinya sendiri sehingga mampu menggapai keberhasilan dan hasil belajar yang bagus dalam setiap mata pelajaran yang diberikan. Keyakinan ini dapat diwujudkan oleh seorang siswa dengan cara berusaha dengan tekun dalam meyelesaikan tugas dan ujian yang diberikan dan pantang menyerah sesulit apapun yang dihadapi, namun hal ini juga harus ditambah dengan peran seorang guru dalam membantu siswa untuk menemukan self efficacy itu didalam dirinya dengan cara mengenali terlebih dahulu kemampuan siswa sebelum menerapkan model pembelajaran dikelas karena sistem dan cara pembelajaran yang sulit dimengerti terutama pada pelajaran yang memang sulit juga akan membuat siswa malas mengikuti pelajaran dan tidak akan merasa nyaman selama pelajaran berlangsung sehingga menyebabkan tidak adanya keyakinan siswa tersebut setiap kali diberikan tugas dan ujian untuk menyelesaikannya, hal semaacam inilah yang mempengaruhi hasil belajar siswa itu sendiri menjadi tidak bagus.

Kesimpulan untuk hasil pada hipotesis dalam penelitian ini dari pernyataan diatas didukung oleh hasil dari penelitian Jex dan Bliese (dalam Efendi 2013: 62) namun berbeda dengan Siswa yang mempunyai tingkat keyakinan yang tinggi disekolah akan merasa nyaman ketika menghadapi keadaan apapun yang terjadi dikelas, hal semacam inilah yang membuat siswa yang bersangkutan akhirnya bisa bertahan dan sangat teguh dalam menghadapi situasi situasi yang sulit penuh dengan hambatan demi mendapatkan nilai yang bagus, karena dengan keyakinan yang mereka miliki mereka sanggup memperjuangkannya meskipun berat dan penuh tekanan.

Dalam penelitian Cervato \& Kerton (2017: 84) juga mengatakan pada dasarnya ketika siswa mampu menyelesaikan tugas yang diberikan dengan baik dan berhasil maka akan meningkatkaan kepercayaan dirinya akan kemampuan yang ia miliki hal inilah yang akhirnya mampu meningkatkan self efficacy pada diri siswa tersebut meskipun self efficaccy siswa rendah namun tetap diharapkan justru guru pra-jabatan memiliki potensi agar bisa mempengaruhi beberapa dari generasi siswa sepanjang karir mereka nantinya karena point pentingnya self efficacy merupakan domain tertentu yang bergantung pada konteks serta secara langsung berkaitan dengan pencapaian akan tugas tertentu siswa sehingga ketika pengajaran self efficacy ditingkatkan lebih tinggi maka akan berkorelasi dengan peningkatan pada pembelajaran siswa juga.

Dalam penelitian lain juga menyatakan bahwa terdapat pengaruh antara self efficacy seorang 
Studi Analisis Hubungan..

siswa terhadap hasil belajar, penelitian ini juga didukung oleh temuan penelitian sebelumnya yang menjelaskan berkualitasnya seorang siswa bukan hanya diukur dari latar belakang pendidikan orang tua ataupun asal sekolah namun dilihat dari keyakinan diriya akan potensi yang dimilikinya dari Granito (2016). Kemudian didukung juga oleh penelitian bandura (1977) bahwa sebuah efikasi diri merupakan keyakinan yang cukup kuat untuk mendorong seseorang mengahasilkan hasil yang terbaik, dan masih banyak lagi penelitian lainnya yang mendukung hal ini.

\section{PENUTUP}

Berdasarkan hasil dari penelitian dan hipotesis yang telah diajukan maka dapat ditarik kesimpulan untuk menjawab rumusah masalah yang sudah dibuat bahwa ada hubungan antara self efficaccy dengan hasil belajar fisika siswa sebagaimana sesuai dengan hasil uji hipotesis data yang sudah dilakukan. Berdasarkan dari hasil penelitian dan kesimpulan tersebut maka saran yang dapat disampaikan oleh peneliti terutama bagi penelitian selanjutnya yaitu: (1) Peneliti melihat hasil belajar dalam penelitian ini dipengaruhi dua faktor yaitu faktor psikis dan juga faktor pisik dalam pelaksanaannya dilapangan; (2) Peneliti menyadari hal yang belum sempat diteliti dan mungkin bisa dilakukan oleh peneliti selanjutnya yaitu menambahkan jumlah subyek tanpa dibatasi serta melakukan tes soal dan juga tes angket self efficacy setiap selesai satu materi pembelajaran; (3) Peneliti juga mengalami kendala selama melaksanakan penelitian terutama mengontrol kejujuran siswa pada saat pengisian angket dan juga soal, hal ini disebabkan kurangnya pemahaman siswa akan makna self efficacy dalam dirinya agar sinkron dengan hasil pembelajaran yang ingin ditingkatkan.

\section{DAFTAR PUSTAKA}

Agustin, F., Putri, R., Fakhruddiana, F., Psikologi, F., Ahmad, U., \& JI, D. (2018). Self-efficacy guru kelas dalam membimbing siswa slow learner. Jurnal Pendidikan Khusus, 14(1).

Ahriana. (2016). Studi Analisis Hubungan Antara Self Efficacy dengan Hasil Belajar Fisika Siswa. Jurnal Pendidikan Fisika Universitas Muhammadiyah Makassar 4.

Cervato, B. C., \& Kerton, C. (2017). Improving the Science Teaching Self- Efficacy of Preservice Elementary. 47(2), 83-91.

Efendi, R. (2013). Journal of Social and Industrial Psychology. 2(2).

Granito, V. J., \& Santana, M. E. (2016). Psychology of Learning Spaces: Impact on Teaching and Learning. 5(1).

Safitri, L., Maruddani, D. A. I., \& Santoso, R. (2017). Analisis Faktor-Faktor yang Mempengaruhi Dividend Payout Ratio (DPR) Menggunakan Analisis Regresi Linier dengan Bootstrap (Studi Kasus: PT. Unilever Indonesia, Tbk Tahun 1999-2015). 6, 385-395.

Tenaw, Y. A. (2013). Relationship Between Self-Efficacy, Academic Achievemnt And Gender In Analitycal Chemistry at. 3(January), 3-28.

Yoannita, B., Budi, E., \& Rustana, C. E. (2016). Pengaruh Self Efficacy Terhadap Hasil Belajar Fisika Melalui Penggunaan Model Problem Based Learning. $V$.

Zumro, M., Setyarsih, W., \& Rohmawati, L. (2018). Identifikasi Awal Profil Self-Efficacy Siswa SMA , Hasil Belajar Fisika , dan Model Pengajarannya. 07(01). 